\title{
Continuous infusion of oxytocin prevents induction of uterine oxytocin receptor and blocks luteal regression in cyclic ewes
}

\author{
A. P. F. Flint and E. L. Sheldrick \\ AFRC Institute of Animal Physiology, Babraham, Cambridge CB2 4AT, U.K.
}

\begin{abstract}
Summary. Continuous intravenous infusion of oxytocin $(3 \mu \mathrm{g} / \mathrm{h})$ between Days 13 and 21 after oestrus delayed return to oestrus by 7 days (length of cycle $23 \cdot 3 \pm 0.6$ days compared to $16.6 \pm 0.2$ days in control ewes). At a lower infusion rate $(0.3 \mu \mathrm{g} / \mathrm{h})$ oxytocin delayed luteolysis in only 2 of 5 ewes. Treatment from Day 14, when luteolysis had already begun, was ineffective. Delay of luteal regression by oxytocin had no effect on the length of subsequent cycles. Measurement of circulating progesterone concentrations and luteal weight showed that prolongation of the oestrous cycle was due to prevention of luteal regression. Luteal regression and behavioural oestrus were induced during continuous oxytocin administration begun on Day 13 when cloprostenol was given on Day 15 (mean cycle length, $17 \cdot 3 \pm 0.21$ days).

Continuous oxytocin infusion from Day 13 blocked the rise in uterine oxytocin receptor concentrations which normally precedes oestrus. Mean receptor concentrations in caruncular and intercaruncular endometrium and in myometrium were 76 , 36 and $9 \mathrm{fmol} / \mathrm{mg}$ protein on Day 17 in ewes receiving continuous oxytocin $(3 \mu \mathrm{g} / \mathrm{h})$; in control ewes these values were 675,638 and $130 \mathrm{fmol} / \mathrm{mg}$ protein respectively at oestrus. Receptor concentrations on the day of oestrus in ewes receiving oxytocin and cloprostenol were not significantly different from those in control ewes $(649,852$, and $109 \mathrm{fmol} / \mathrm{mg}$ protein respectively).

Since cloprostenol, a PGF-2 $\alpha$ analogue, overcame the antiluteolytic action of oxytocin, it is suggested that continuous oxytocin treatment may inhibit uterine production of PGF-2 $\alpha$, possibly by down regulating the uterine oxytocin receptor. Failure of oxytocin to prevent the rise in oxytocin receptor after cloprostenol may indicate that the process of down regulation is progesterone dependent.
\end{abstract}

\section{Introduction}

There is a good deal of evidence to suggest that oxytocin is involved in the process leading to luteal regression in ruminants. Oxytocin administered early in the luteal phase of the oestrous cycle causes luteolysis in cattle (Armstrong \& Hansel, 1959) and goats (Cooke \& Knifton, 1981), and some degree of luteal regression in sheep (Milne, 1963; Dobrowolski, 1973; Hatjiminaglou, Alifakiotis \& Zervas, 1979), probably through a stimulatory effect on uterine prostaglandin (PG) F-2 $\alpha$ secretion (Hansel \& Wagner, 1960; Sharma \& Fitzpatrick, 1974; Mitchell, Flint \& Turnbull, 1975; Roberts, McCracken, Gavagan \& Soloff, 1976). Episodes of secretion of PGF-2 $\alpha$ occur simultaneously with those of oxytocin (Flint \& Sheldrick, 1983) or oxytocin neurophysin (Fairclough et al., 1980) at luteal regression and both active and passive immunization against oxytocin lead to a delay in luteolysis (Sheldrick, Mitchell \& Flint, 1980; Schams, Prokopp \& Barth, 1983).

An important potential source of oxytocin at luteal regression is the corpus luteum itself. The corpora lutea of sheep and cattle contain high concentrations of oxytocin (Wathes \& Swann, 1982; 
Flint \& Sheldrick, 1982a; Fields, Eldridge, Fuchs, Roberts \& Fields, 1983) which is secreted into the ovarian vein (Flint \& Sheldrick, 1982b). Secretion is stimulated by PGF-2 $\alpha$ analogues (Flint \& Sheldrick, 1982b, 1983). The significance of luteal oxytocin secretion in response to PGF-2 $\alpha$ may lie in the positive feedback loop constituted by this process together with the release of PGF- $2 \alpha$ from the uterus in response to oxytocin (Flint \& Sheldrick, 1983; Sheldrick \& Flint, 1983a). Such a positive feedback loop has been suggested to account for the episodic secretion of uterine PGF- $\alpha$ (Flint \& Sheldrick, 1983), which is an important requirement for its maximum luteolytic potency (Schramm, Bovaird, Glew, Schramm \& McCracken, 1983).

Maintenance of luteal function in early pregnancy is accompanied by loss of oxytocin from the corpora lutea (Sheldrick \& Flint, 1983b) and it appears that one way in which such a positive feedback loop may be controlled is through alterations in the synthesis of oxytocin by the corpus luteum. Loss of luteal oxytocin, which occurs when luteal function is prolonged beyond the normal time of regression (Flint \& Sheldrick, 1985), may facilitate luteal maintenance through the absence of oxytocin-induced episodes of PGF-2 $\alpha$ secretion (Sheldrick \& Flint, 1984).

The operation of the positive-feedback loop may also be controlled by availability of the oxytocin receptor in the uterus. Levels of oxytocin receptor increase at luteal regression in both myometrium and endometrium (Roberts et al., 1976; Sheldrick \& Flint, 1985), and there is a parallel increase in uterine sensitivity in terms of both contractility (McCracken, Schramm \& Okulicz, 1984) and PGF-2 $\alpha$ secretion (Roberts et al., 1976).

The experiments described here were undertaken to determine whether continuous infusion of oxytocin had any effect on the operation of the positive-feedback loop, and particularly on uterine concentrations of the oxytocin receptor.

\section{Materials and Methods}

Animals. Clun Forest ewes kept in paddocks with crayon-bearing vasectomized rams were examined daily for oestrous behaviour. All 37 ewes cycled spontaneously, and all had exhibited at least 2 oestrous cycles (mean \pm s.e.m. length, $16 \cdot 6 \pm 0 \cdot 10$ days; $n=98$ ) before experimentation. The experiments were performed in November and December 1982, between November 1983 and February 1984 and during October 1984 . Since identical results were obtained during each breeding season the data have been pooled for purposes of presentation.

The animals were assigned at random to 8 experimental groups, as follows: Group 1, 7 control ewes infused with sterile saline $(0.9 \% \mathrm{w} / \mathrm{v} \mathrm{NaCl})$ beginning on Day 13 (oestrus = Day 0 ); Group 2 , 6 ewes treated with oxytocin $(3 \mu \mathrm{g} / \mathrm{h})$ in sterile saline from Day 13; Group 3, 5 ewes treated with oxytocin $(0.3 \mu \mathrm{g} / \mathrm{h})$ from Day 13; Group 4, 5 ewes treated with oxytocin $(3 \mu \mathrm{g} / \mathrm{h})$ from Day 14 ; Group 5, 6 ewes treated with oxytocin $(3 \mu \mathrm{g} / \mathrm{h})$ from Day 13 , which also received $125 \mu \mathrm{g}$ cloprostenol (Estrumate: I.C.I. 80996; I.C.I. Ltd, Macclesfield, Cheshire, U.K.) i.m. on Day 15. In Groups 1-5 the infusions started on Days 13 or 14 were maintained until the animals returned to oestrus or, when oestrus was delayed, until Day 21; ewes with delayed oestrus were returned to the paddock on Day 21 and the day of oestrus was noted. Uterine oxytocin receptors were measured in Groups 6-8, which comprised 5 ewes each, as follows: Group 6, 5 control ewes (2 from Group 1) killed on the day of oestrus; Group 7, 5 ewes treated with oxytocin $(3 \mu \mathrm{g} / \mathrm{h})$ from Day 13 and killed on Day 17 (none of which was in oestrus on or before Day 17); and Group 8, 5 ewes from Group 5, killed on the day of oestrus after cloprostenol treatment (Days 17 or 18).

All ewes receiving infusions were kept in metabolism cages under conditions that allowed blood samples to be obtained without disturbing the animals (Flint \& Sheldrick, 1983). Two polyvinylchloride catheters, o.d. $2 \cdot 1 \mathrm{~mm}$, were inserted in the external jugular veins, under local anaesthesia, by the method of Seldinger (1953). One catheter was used for withdrawal of blood samples twice daily for progesterone and oxytocin determination. The second catheter (in the other jugular vein) was used for infusion of saline or oxytocin (Bachem Inc, Torrance, CA, U.S.A.), which was prepared in solution in sterile physiological saline $(1 \mu \mathrm{g} / \mathrm{ml}$ or $0 \cdot 1 \mu \mathrm{g} / \mathrm{ml})$. All solutions were infused, 
using a peristaltic pump, at $0.05 \mathrm{ml} / \mathrm{min}$. The ewes were removed from the cages daily (usually between 14:00 and 16:00 h) for testing for oestrous behaviour with a vasectomized ram, which was kept in the same room as the ewes. This involved disconnecting the infusion catheter for periods of up to $20 \mathrm{~min}$; otherwise infusions were continuous.

To ensure that circulating oxytocin concentrations were similar when collecting tissues from animals killed during oxytocin infusion, the infusions were discontinued 30 min before administering a lethal dose of pentobarbitone sodium.

Determination of uterine oxytocin receptor concentrations. Membrane fractions were prepared by differential centrifugation from homogenates in $25 \mathrm{~mm}$-Tris- $\mathrm{HCl}$, pH 7.6 containing $0 \cdot 25$ M-sucrose and 1 mM-EDTA, from the 15 ewes in Groups 6-8, as described by Sheldrick \& Flint (1985). Receptor fractions were prepared from caruncular and intercaruncular endometrium and from myometrium separately in each case, and were frozen in aliquants at $-60^{\circ} \mathrm{C}$ until assay. Receptor preparations were stable during storage for up to 6 months (E. L. Sheldrick, unpublished observations).

Oxytocin receptor concentrations were determined by incubation of membrane fractions $(50 \mu \mathrm{g}$ protein) with $5 \mathrm{~nm}-\left[3,4-{ }^{3} \mathrm{H}-\mathrm{Tyr}\right]$ oxytocin (sp. act. $27 \mathrm{Ci} / \mathrm{mmol}$; Cambridge Research Biochemicals, Harston, Cambridge, U.K.) for $15 \mathrm{~min}$ at $25^{\circ} \mathrm{C}$ in the presence of $1 \mathrm{~mm}-\mathrm{Mn} \mathrm{Cl}_{2}$ (Sheldrick \& Flint, 1985). Separation of bound and free $\left[{ }^{3} \mathrm{H}\right]$ oxytocin was carried out on Millipore (Durapore, Type GVWP) filters.

Because of the possible inhibition of binding of $\left[{ }^{3} \mathrm{H}\right]$ oxytocin in the receptor assay by oxytocin present in receptor fractions prepared from oxytocin-treated ewes, a method was developed for measuring oxytocin receptor concentrations after dissociating oxytocin from occupied receptors. This procedure, which was based on that of Hollenberg \& Nexø (1981), involved treatment of receptor fractions with acid. Receptor fractions pipetted onto Durapore membranes in the vacuum filtration apparatus were preincubated for $1 \mathrm{~min}$ with $0.5 \mathrm{ml} 0.9 \%(\mathrm{w} / \mathrm{v}) \mathrm{NaCl}$ adjusted to $\mathrm{pH} \mathrm{4.0}$ with $\mathrm{HCl}$. The medium was removed under vacuum and the receptor fractions washed once with

Table 1. Effects of continuous infusion of oxytocin on oestrous cycle length in sheep

\begin{tabular}{|c|c|c|c|c|}
\hline Group & Treatment & $\begin{array}{l}\text { No. of } \\
\text { ewes }\end{array}$ & $\begin{array}{c}\text { No. of ewes } \\
\text { with prolonged } \\
\text { cycles } \\
(>18 \text { days) }\end{array}$ & $\begin{array}{c}\text { Mean } \pm \text { s.e.m. } \\
\text { length of } \\
\text { cycle } \\
\text { (days) }\end{array}$ \\
\hline 1 & $\begin{array}{l}\text { Saline } \\
\text { (Day } 13 \text { oestrus) }\end{array}$ & 7 & 0 & $16 \cdot 6 \pm 0 \cdot 20$ \\
\hline 2 & $\begin{array}{l}\text { Oxytocin } \\
(3 \mu \mathrm{g} / \mathrm{h} ; \text { Days } 13-21)\end{array}$ & 6 & 6 & $23 \cdot 3 \pm 0 \cdot 67$ \\
\hline 3 & $\begin{array}{l}\text { Oxytocin } \\
(0 \cdot 3 \mu \mathrm{g} / \mathrm{h} \text {; from Day } 13)\end{array}$ & 5 & $2^{*}$ & $18 \cdot 8 \pm 1.62$ \\
\hline 4 & $\begin{array}{l}\text { Oxytocin } \\
(3 \mu \mathrm{g} / \mathrm{h} \text {; from Day } 14)\end{array}$ & $\begin{array}{l}4 \dagger \\
1 \ddagger\end{array}$ & $\begin{array}{l}0 \\
1\end{array}$ & $16 \cdot 0 \pm 0 \cdot 00$ \\
\hline 5 & $\begin{array}{l}\text { Oxytocin } \\
(3 \mu \mathrm{g} / \mathrm{h} \text { from Day } 13 \\
\text { plus cloprostenol } \\
\text { on Day } 15)\end{array}$ & 6 & 0 & $17 \cdot 3 \pm 0 \cdot 21$ \\
\hline
\end{tabular}

* Cycle prolonged to 19 and 25 days.

Ewes in which luteolysis had begun before starting oxytocin infusion.

$\ddagger$ No decline in circulating progesterone before treatment begun. 
$0.5 \mathrm{ml} 0.9 \%(\mathrm{w} / \mathrm{v}) \mathrm{NaCl}, \mathrm{pH} 4.0$, and 3 times with $2 \mathrm{ml} 25 \mathrm{~mm}-$ Tris- $\mathrm{HCl} \mathrm{pH} 7.6$ containing $0.1 \%$ bovine serum albumin. The usual reagents were then used for receptor assay in a volume of $0.1 \mathrm{ml}$. When this technique for stripping receptors of bound oxytocin was validated by measuring binding of $\left[{ }^{3} \mathrm{H}\right]$ oxytocin before and after stripping in receptor fractions prepared from untreated ewes, binding after stripping was $114 \pm 14 \%$ of that measured before stripping. Therefore treatment with acid did not lead to receptor loss.

Radioimmunoassays. Progesterone concentration in jugular and ovarian venous plasma was measured after extraction with diethyl ether as described and validated for sheep plasma by Sheldrick et al. (1980). Sensitivity of the assays reported here (calculated from $2 \times$ s.d. below the zero mass-added point, $B_{o}$ ) was $8.70 \mathrm{pg} /$ tube, equivalent to $0.10 \mathrm{ng} / \mathrm{ml}$ plasma. Intra- and interassay coefficients of variation were 7.0 and $10.6 \%$ respectively, and extraction recovery was $87 \cdot 5 \pm 0 \cdot 4 \%$. Values were corrected for losses during extraction.

Oxytocin was measured in jugular venous plasma after extraction with activated glass powder as validated for sheep plasma by Sheldrick \& Flint (1981). Extraction recoveries of ${ }^{125}$ I-labelled oxytocin added to plasma samples were $81 \pm 1.5 \%$. The sensitivity of the assay was $0.4 \mathrm{pg} /$ tube (equivalent to $0.49 \mathrm{pg} / \mathrm{ml}$ plasma). Intra- and interassay coefficients of variation were 7.9 and $11 \cdot 5 \%$ respectively. Values were corrected for extraction losses.

Statistical analysis. All values are expressed as means \pm s.e.m. Statistical probabilities for differences between experimental groups were tested by Student's $t$ test.

\section{Results}

\section{Effects of oxytocin infusion on cycle length}

When oxytocin was infused $(3 \mu \mathrm{g} / \mathrm{h})$ between Days 13 and 21 of the cycle, the onset of behavioural oestrus was consistently blocked (Table 1). After cessation of treatment on Day 21, the animals displayed oestrus between 0 and 4 days later, the mean time of return to oestrus being 23.3 days. In control animals infused with vehicle from Day 13 the mean time of return to oestrus was 16.6 days. Continuous infusion of oxytocin $(3 \mu \mathrm{g} / \mathrm{h})$ beginning on Day 14 had no effect in 4 of the 5 animals tested, but delayed oestrus until Day 43 in one ewe. Reducing the dose to $0.3 \mu \mathrm{g} / \mathrm{h}$ (starting on Day 13) delayed oestrus (to Days 19 and 25) in 2 of 5 animals treated.

\section{Hormone concentrations in treated ewes}

Continuous infusion of oxytocin $(3 \mu \mathrm{g} / \mathrm{h})$ from Day 13 prevented the decline in circulating concentrations of progesterone normally associated with luteal regression between Days 13 and 16, and raised circulating concentrations of oxytocin. Typical results from one treated and one control ewe are shown in Text-fig. 1. Mean corpus luteum weights and circulating progesterone concentrations were raised in oxytocin-infused ewes killed on Day 17 compared to saline-treated or oxytocin + cloprostenol-treated animals (Table 2). Progesterone levels in ewes treated with $0 \cdot 3 \mu \mathrm{g}$ oxytocin/h (Group 3) showed that treatment was ineffective in blocking luteolysis in 3 of 5 cases. Oxytocin had no effect on cycle length in 4 animals in which luteolysis had started before infusion began on Day 14 (Text-fig. 1); circulating progesterone values were high at the start of infusion in the fifth animal in Group 4, in which the cycle was prolonged (data not shown).

\section{Effect of continuous infusion of oxytocin on uterine concentrations of the oxytocin receptor}

Oxytocin receptor concentrations in all 3 uterine tissues were low in ewes receiving oxytocin infusions $(3 \mu \mathrm{g} / \mathrm{h}$ ) from Day 13 (Group 7), compared with levels in control ewes (Group 6) on the 


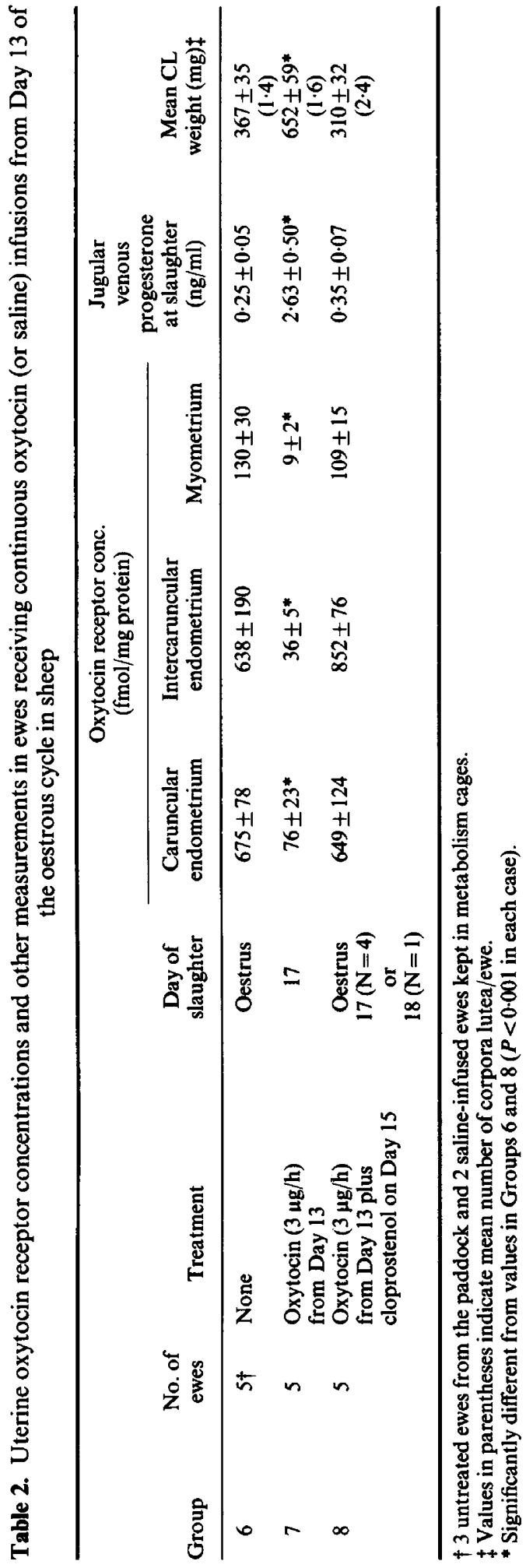


(a)

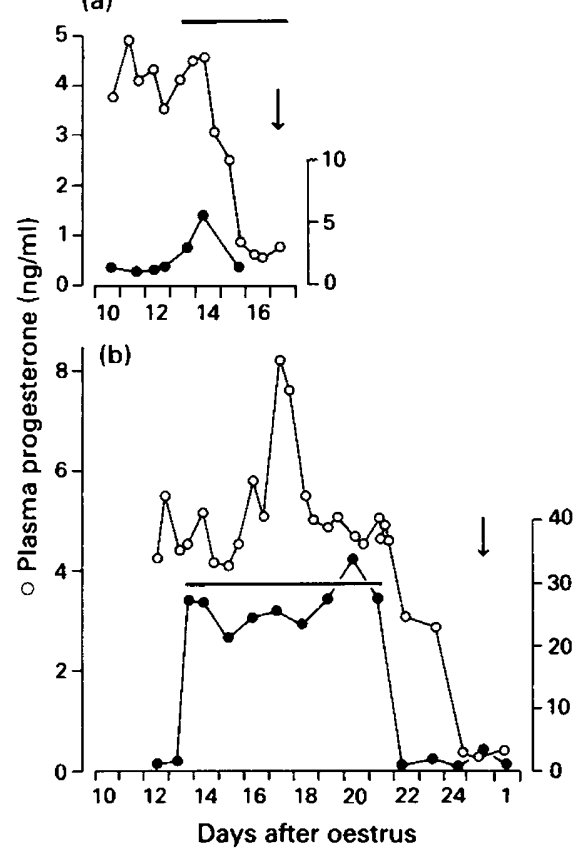

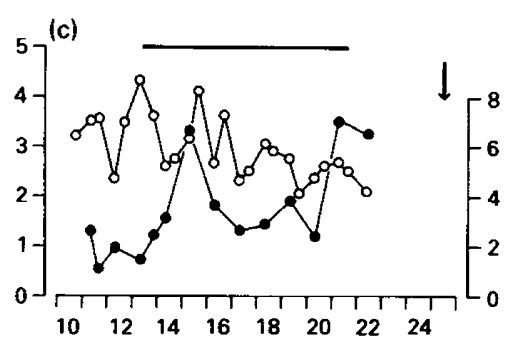

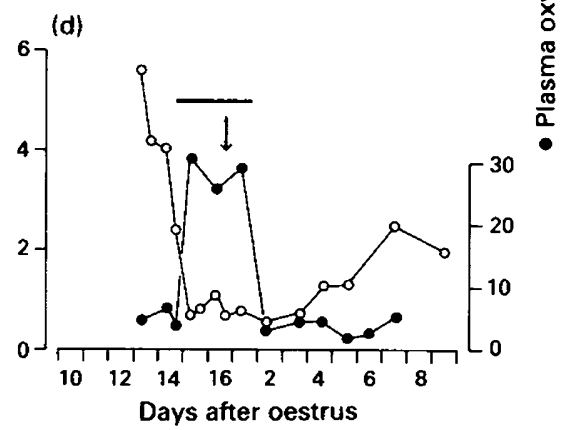

Text-fig. 1. Effects of infusion of saline or oxytocin on jugular venous progesterone and oxytocin concentrations in single representative ewes from (a) Group 1, saline infusion from Day 13; (b) Group 2, oxytocin (3 $\mu \mathrm{g} / \mathrm{h})$ from Day 13; (c) Group 3, oxytocin $(0.3 \mu \mathrm{g} / \mathrm{h})$ from Day 13; (d) Group 4, oxytocin $(3 \mu \mathrm{g} / \mathrm{h})$ from Day 14 . Solid bars indicate periods of infusion; vertical arrows denote oestrus behaviour.

day of oestrus. Receptor levels in these 2 groups were inversely related to circulating progesterone concentrations and luteal weights, both of which remained high in treated ewes, but were low in those in oestrus.

Experiments in which receptor concentrations were determined with and without acid stripping indicated that residual unlabelled oxytocin present in receptor preparations from oxytocin-treated ewes did not interfere with receptor measurements. Receptor levels were not increased by acid stripping, probably because oxytocin infusions were discontinued $30 \mathrm{~min}$ before slaughter, and because tissues were extracted in medium containing EDTA, which causes dissociation of receptor-oxytocin complexes (Sheldrick \& Flint, 1985).

\section{Treatment of infused ewes with cloprostenol}

Administration of cloprostenol (125 $\mu \mathrm{g}$ i.m.) on Day 15 to 6 ewes in which continuous infusion of oxytocin was started on Day 13 resulted in the onset of behavioural oestrus on Day $17(\mathrm{~N}=4)$ or $18(\mathrm{~N}=2)$ despite maintenance of oxytocin treatment (Group 5, Table 1). In each of these animals luteal regression had occurred before oestrus, as indicated by circulating progesterone concentrations (typical example shown in Text-fig. 2). In 5 of these animals, which were killed on the day of oestrus, mean concentrations of oxytocin receptor in caruncular and intercaruncular endometrium and in myometrium were $649,852 \mathrm{nd} 109 \mathrm{fmol} / \mathrm{mg}$ protein respectively. These values were significantly raised compared to those in oxytocin-infused ewes not receiving cloprostenol (Group 7;P<0.001 in each tissue) but were not significantly different from values in control ewes at oestrus (Group 6;P>0.1 in each tissue). Luteal weights and circulating progesterone concentrations were reduced by cloprostenol, despite continued oxytocin infusion. 


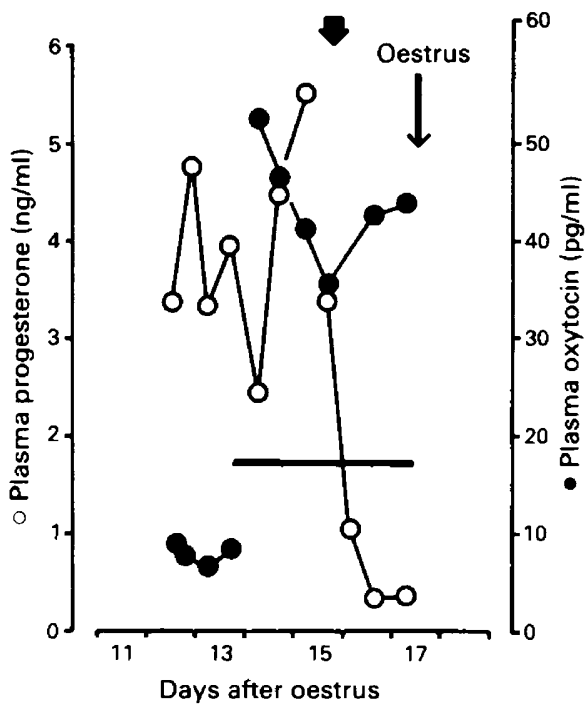

Text-fig. 2. Effect of administration of cloprostenol ( $125 \mu \mathrm{g}$, i.m., arrow) on jugular venous progesterone and oxytocin concentrations in a representative ewe from Group 5. Oxytocin infusion (solid bar) was begun on Day 13; oestrous behaviour was noted on Day. 17.

\section{Effect of oxytocin infusion on length of subsequent cycles}

Continuous infusion of oxytocin in one cycle had no effect on oestrous cycle length in subsequent cycles, measured from the day of oestrus after withdrawal of infusion. Mean length of the cycles immediately following the prolonged cycle for 6 ewes in which luteal regression was delayed was $17.8 \pm 0.31$ days; this value was not significantly different from the length of the cycle before treatment in these ewes $(17.3 \pm 0.48$ days) or of the cycle after treatment in control animals $(17 \cdot 5 \pm 0.29$ days $)$.

\section{Discussion}

These experiments have demonstrated for the first time that the continuous infusion of oxytocin prevents luteal regression and thereby delays the onset of behavioural oestrus in cyclic ewes. Questions arising from this observation are, firstly, what is the mechanism by which oxytocin exerts this effect? And secondly, can this response be exploited therapeutically?

One hypothesis to account for the effect of continuous oxytocin infusion is that this treatment down regulated oxytocin receptors, and there is evidence supporting this suggestion: uterine receptor levels were low in animals given continuous infusions of oxytocin, at a time (Day 17) when they were high in control ewes, and the effect of oxytocin does not appear to be exerted on the hypothalamus, pituitary or directly on the ovary, since oestrus was induced normally in animals receiving oxytocin by administration of cloprostenol, and since oxytocin infusion from Day 14 was ineffective in blocking the onset of oestrus. The fact that cloprostenol, a PGF- $2 \alpha$ analogue, overcame the effect of oxytocin suggests that luteolysis was delayed as a result of a lack of PGF-2 $\alpha$, and this is consistent with failure of the action of oxytocin on the uterus. However, the finding that oestrus after cloprostenol treatment in oxytocin-infused ewes was accompanied by a marked increase in uterine oxytocin receptor concentrations is difficult to reconcile with the downregulation hypothesis, since these ewes received a dose of oxytocin apparently sufficient to cause 
down regulation in the absence of cloprostenol. To accommodate this observation while retaining the down-regulation hypothesis it may be postulated that the process of down regulation of the oxytocin receptor requires continued exposure of the uterus to progesterone. The increased turnover of the oxytocin receptor induced by progesterone in explants of rat uterus in organ culture (Soloff et al., 1983) is consistent with such an effect, but there appear to be no comparable data for the sheep.

An alternative hypothesis is that oxytocin infusion prevents progesterone withdrawal by another mechanism and that the low uterine oxytocin receptor levels on Day 17 in treated ewes reflect, rather than cause, the failure of luteolysis. The major rise in oxytocin receptor at oestrus appears to be closely linked to declining levels of progesterone (Sheldrick \& Flint, 1985) and the induction of the receptor by oestrogen can be blocked by progesterone both in vivo (Nissenson, Flouret \& Hechter, 1978) and in vitro (Soloff et al., 1983); there is therefore evidence that such a mechanism might operate. As reviewed above it appears most likely that oxytocin infusion delays luteolysis through an inhibitory action on PGF- $2 \alpha$ secretion; it is possible, therefore, that oxytocin affects prostaglandin synthesis, perhaps by reducing the availability of substrate to the synthetase, as a result of interacting with the relatively low levels of oxytocin receptor in the uterus on Day 13 of the cycle. It is not possible on the evidence at present available to decide between these hypothetical mechanisms of action.

The data presented here suggest that continuous oxytocin administration may be used to treat the syndrome of luteal insufficiency in animals (e.g. ruminants) for which there is evidence that oxytocin is involved in the control of luteal function. One condition associated with luteal insufficiency in cattle is embryonic mortality, which may be ameliorated in some herds by administration of hCG or progesterone (see Sreenan \& Diskin, 1983). As well as occurring spontaneously, such luteal insufficiency is frequently prominent in animals in which ovulation is induced by treatment with LHRH (Haresign, Foster, Haynes, Crighton \& Lamming, 1975). Continuous oxytocin treatment appears to have potential advantages in this context, since whereas administration of progesterone can cause luteal regression, presumably through reduced secretion of LH (Ginther, 1968), oxytocin administered continuously in the late luteal phase does not have this effect. The uninterrupted administration of oxytocin appears to be important to elicit an antiluteolytic action, since daily injections during the late luteal phase in cattle are ineffective (Hansel \& Wagner, 1960). Appropriate administration of oxytocin might therefore be expected to lead to a more competent corpus luteum after cessation of treatment.

We are grateful to Dr P. W. Sheppard, Cambridge Research Biochemicals, for preparations of $\left[3,4-{ }^{3} \mathrm{H}-\mathrm{Tyr}\right]$ oxytocin. The contents of this paper are the subject of a patent application, enquiries about which should be directed to the British Technology Group, 101 Newington Causeway, London SE1 6BU, U.K.

\section{References}

Armstrong, D.T. \& Hansel, W. (1959) Alteration of the bovine estrous cycle with oxytocin. J. Dairy Sci. 42, $533-542$.

Cooke, R.G. \& Knifton, A. (1981) Oxytocin induced oestrus in the goat. Theriogenology 16, 95-97.

Dobrowolski, W. (1973) Wplyw oksytocyny na cykl plciowy owcy w sexonie rozplodu i ciszy seksualnej. Polskie Archwm wet. 16, 649-654.

Fairclough, R.J., Moore, L.G., McGowan, L.T., Peterson, A.J., Smith, J.F., Tervit, H.R. \& Watkins, W.B. (1980) Temporal relationship between plasma concentrations of 13,14-dihydro-15-keto-prostaglandin $F$ and neurophysin $\mathbf{I} / \mathbf{I I}$ around luteolysis in sheep. Prostaglandins 20, 199-208.
Fields, P.A., Eldridge, R.K., Fuchs, A.-R., Roberts, R.F. \& Fields, M.J. (1983) Human placental and bovine corpora luteal oxytocin. Endocrinology 112, $1544-1546$.

Flint, A.P.F. \& Sheldrick, E.L. (1982a) Ovarian secretion of oxytocin in the sheep. J. Physiol., Lond. 330, $61 P-62 P$, Abstr.

Flint, A.P.F. \& Sheldrick, E.L. (1982b) Ovarian secretion of oxytocin is stimulated by prostaglandin. Nature, Lond. 297, 587-588.

Flint, A.P.F. \& Sheldrick, E.L. (1983) Evidence for a systemic role for ovarian oxytocin in luteal regression in sheep. J. Reprod. Fert. 67, 215-225.

Flint, A.P.F. \& Sheldrick, E.L. (1985) Ovarian oxytocin. 
In Oxytocin: Clinical and Laboratory Studies, pp. 335-350. Eds J. Amico \& A. G. Robinson, Elsevier, Amsterdam.

Ginther, O.J. (1968) Influence of exogenous progesterone and the uterus on ovarian activity in sheep. Endocrinology 83, 613-615.

Hansel, W. \& Wagner, W.C. (1960) Luteal inhibition in the bovine as a result of oxytocin injections, uterine dilatation, and intrauterine infusions of seminal and preputial fluids. J. Dairy Sci. 43, 796-805.

Haresign, W., Foster, J.P., Haynes, N.B., Crighton, D.B. \& Lamming, G.E. (1975) Progesterone levels following treatment of seasonally anoestrous ewes with synthetic LH-releasing hormone. J. Reprod. Fert. 43, 269-279.

Hatjiminaglou, I., Alifakiotis, T. \& Zervas, N. (1979) The effect of exogenous oxytocin on estrous cycle length and corpus luteum lysis in ewes. Annls Biol. anim. Biochim. Biophys. 19, 355-365.

Hollenberg, M.D. \& Nexø, E. (1981) Receptor binding assays. In Membrane Receptors: Method for Purification and Characterization; Receptors and Recognition, Series B, vol. 11, pp. 1-31. Eds S. Jacobs \& P. Cuatrecasas. Chapman and Hall, London.

McCracken, J.A., Schramm, W. \& Okulicz, W.C. (1984) Hormone receptor control of pulsatile secretion of $\mathrm{PGF}_{2 \alpha}$ from the ovine uterus during luteolysis and its abrogation in early pregnancy. Anim. Reprod. Sci. 7, $3 !-55$.

Milne, J.A. (1963) Effects of oxytocin on the oestrous cycle of the ewe. Aust. vet. J. 39, 51-52.

Mitchell, M.D., Flint, A.P.F. \& Turnbull, A.C. (1975) Stimulation by oxytocin of prostaglandin F levels in uterine venous effluent in pregnant and puerperal sheep. Prostaglandins 9, 47-56.

Nissenson, R., Flouret, G. \& Hechter, O. (1978) Opposing effects of estradiol and progesterone on oxytocin receptors in rabbit uterus. Proc. natn. Acad. Sci. U.S.A. 75, 2044-2048.

Roberts, J.S., McCracken, J.A., Gavagan, J.E. \& Solofi, M.S. (1976) Oxytocin-stimulated release of prostaglandin $F_{2 a}$ from ovine endometrium in vitro: correlation with estrous cycle and oxytocin-receptor binding. Endocrinology 99, 1107-1114.

Schams, D., Prokopp, S. \& Barth, D. (1983) The effect of active and passive immunization against oxytocin on ovarian cyclicity in ewes. Acta endocr., Copenh. 103, 337-344.
Schramm, W., Bovaird, L., Glew, M.E., Schramm, G. \& McCracken, J.A. (1983) Corpus luteum regression induced by ultra-low pulses of prostaglandin $F 2 \alpha$. Prostaglandins 26, 347--364.

Seldinger, S.I. (1953) Catheter replacement of the needle in percutaneous arteriography. Acta radiol. 39, 368-376.

Sharma, S.C. \& Fitzpatrick, R.J. (1974) Effect of oestradiol-17 $\beta$ and oxytocin treatment on prostaglandin $F$ alpha release in the anoestrous ewe. Prostaglandins 6, 97-105.

Sheldrick, E.L. \& Flint, A.P.F. (1981) Circulating concentrations of oxytocin during the estrous cycle and early pregnancy in sheep. Prostaglandins 22, 631-636.

Sheldrick, E.L. \& Flint, A.P.F. (1983a) Regression of the corpora lutea in sheep in response to cloprostenol is not affected by loss of luteal oxytocin after hysterectomy. J. Reprod. Fert. 68, 155-160.

Sheldrick, E.L. \& Flint, A.P.F. (1983b) Luteal concentrations of oxytocin decline during early pregnancy in the ewe. J. Reprod. Fert. 68, 477-480.

Sheldrick, E.L. \& Flint, A.P.F. (1984) Ovarian oxytocin and luteal function in the early pregnant sheep. Anim. Reprod. Sci. 7, 101-113.

Sheldrick, E.L. \& Flint, A.P.F. (1985) Endocrine control of uterine oxytocin receptors in the ewe. $J$. Endocr. 106, 249-258.

Sheldrick, E.L., Mitchell, M.D. \& Flint, A.P.F. (1980) Delayed luteal regression in ewes immunized against oxytocin. J. Reprod. Fert. 59, 37-42.

Solofi, M.S., Fernstrom, M.A., Periyasamy, S., Solofi, S., Baldwin, S. \& Wieder, M. (1983) Regulation of oxytocin receptor concentration in rat uterine explants by estrogen and progesterone. Can. J. Biochem. Cell Biol. 61, 625-630.

Sreenan, J.M. \& Diskin, M.G. (1983) Early embryonic mortality in the cow: its relationship with progesterone concentration. Vet. Rec. 112, 517-521.

Wathes, D.C. \& Swann, R.W. (1982) Is oxytocin an ovarian hormone? Nature, Lond. 297, 225-227. 